\title{
Reaksi Pasar Saham Terhadap Kebijakan Dividen Sebelum dan Sesudah Ex- Dividend Date
}

\author{
Aulia Azizah \\ Magister Manajemen, Fakultas Ekonomi dan Bisnis,Universitas Lambung Mangkurat \\ Email : aulia.azizah11@gmail.com
}

\begin{abstract}
This study aimed to analyzed market reaction caused the announcement of rising dividend or dividend down before and after Ex-dividend date in Indonesia Stock Exchange (IDX).This research used event study method by using abnormal return on share as research variable and used price data of shares as research unit analysis. As the result, 26 companies as the sample of 45 companies which registered in index LQ45 in Indonesia Stock Exchange period 2016-2018 by purposing sampling technique. Measurement of variable using the calculation of the average abnormal return of shares by testing the hypothesis using different test paired sample t-test and Wilxocon related sample test with the help of SPSS version 22.The research result showed there was no difference in abnormal return on share before and after Ex-dividend date in the companies which announced rising dividend and dividend down in Indonesia Stock Exchange (IDX) period 2016-2018. The results of the different paired sample t-test obtained a significance value of 0,486 which was greater than 0,05 and in the Wilxocon test the related sample test obtained $z$ score of 1,478 which was greater than $z$ table which was 1.458. For the next research, it is recommended to test the different indexes and regard to the confounding effect which can lead to bias.
\end{abstract}

Keywords : Dividend, Abnormal Return, Ex-Dividend date, Event Study

Abstrak

Penelitian ini bertujuan untuk menganalisis reaksi pasar saham yang ditimbulkan oleh pengumuman dividen naik atau pengumuman dividen turun sebelum dan sesudah ex-dividend date di Bursa Efek Indonesia (BEI). Metode penelitian ini menggunakan event study dimana menggunakan abnormal return saham sebagai variabel pengujian yang menggunakan data harga saham harian sebagai unit analisi penelitiian. Hasil pengumpulan data diperoleh 26 perusahaan sebagai sampel dari populasi sebanyak 45 perusahaan yang terdaftar di indeks LQ45 di Bursa efek Indonesia periode 2016-2018 dengan teknik sampling secara purposive sampling. Pengukuran variabel menggunakan penghitungan rata- rata abnormal return saham dengan pengujujian hipotesis menggunakan uji beda paired sample t-test dan uji Wilxocon releted sample test dengan bantuan aplikasi SPSS versi 22. Hasil peneltian menyimpulkan tidak terdapat perbedaan abnormal return saham sebelum dan sesudah Ex-dividend date pada perusahaan yang mengumumkan dividen naik atau dividien turun di Bursa Efek Indonesia periode tahun 2016-2018 Hasil uji beda paired sample t-test diperoleh nilai signifikansi sebesar 0,486 yang atinya lebih besar dari 0,05 dan pada uji Wilxocon releted sample test diperoleh z-hitung sebesar 1,478 dimana lebih besar dari z tabel yaitu 1,458. Untuk peneliti selanjutnya disarankan melakukan pengujian pada indeks berbeda dan memperhatikan confounding effect yang dapat memunculkan bias.

Kata Kunci : Dividend, Abnormal Return, Ex-Dividend date, Event Study

(C) 2020 Jurnal Riset Inspirasi Manajemen dan Kewirausahaan

\section{PENDAHULUAN}

Perkembangan pasar modal di Indonesia semakin menunjukan peningkatan. Hal ini dapat terlihat dari jumlah investor yang semakin hari semakin meningkat dimana sampai tahun 2017 PT. Kustodian Sentral Efek Indonesia (KSEI) mencatat jumlah Signal Investor Identification (SID) meningkat $14,7 \%$ dari 894.116 per tahun 2016 menjadi 1.025 .414 per juli tahun 2017. Investor memiliki berbagai macam informasi yang dapat dijadikan dasar dalam menganalisi peluang investasi di pasar modal, salah satu informasi yang sering muncul adalah pengumuman dividen. Pengumuman dividen merupakan salah satu informasi yang ditunggu-tunggu oleh investor karena setiap investor memiliki persepsi yang berbeda-beda mengenai dividen dikarenakan banyaknya teori yang dikemukakan mengenai kebijakan dividen sehingga tiap-tiap investor akan memiliki respon yang berbeda-beda menanggapi pengumuman kebijakan dividen.

Simon-Oke \& Olugunwa (2016) menemukan bahwa pengumuman dividen berpengaruh pada performa perusahaan, karena menurut mereka 
apabila suatu perusahaan melakukan pembagian dividen artinya perusahaan tersebut memperoleh keuntungan yang cukup besar dan investor akan beranggapan bahwa perusahaan tersebut memiliki kinerja yang bagus. Setelah dilakukan pengumuman dividen oleh perusahaan ada masa penting yang dianggap investor sebagai tanggal penting setelah pengumuman dividen yaitu tanggal ex-dividen dimana tanggal tersebut ada batas waktu jual beli saham perusahaan tersebut sebelum tanggal pencatatan investor yang berhak menerima dividen. Dilihat dalam penelitian yang dilakukan Sularso (2003) menunjukan hasil bahwa ada abnormal return yang signifikan terjadi pada hari ke 4 sebelum Ex-dividend date dan hari ke 5 setelah Ex-dividend date pada dividen naik, bahwa ada abnormal return yang signifikan terjadi pada hari ke 13 dan hari ke 2 sebelum Ex-dividend date dan hari ke 5 setelah Ex-dividend date pada dividen turun. Terdapat tanggapan lain yang menyatakan pembagian dividen tidak berpengaruh pada saham dan performa suatu perusahaan berdasarkan hasil penelitian Mondigliani \& Miller (1961) yang menyatakan bahwa dividen dianggap tidak relefan sebagai indikator nilai dari sebuah perusahaan. Didukung oleh Omodero dan Kalu (2017) yang menemuka bahwa pembagian dividen tidak mempengaruhi harga saham karena investor tidak befokus pada dividen tetapi lebih percaya pada kemampuan manajemen dalam mengelola keuangan perusahaan. Penelitian lain juga mendukung bahwa pengumuman dividen tidak berpengaruh pada harga saham yang akan memunculkan abnormal return pada hari disekitar pengumuman dividen yang menurut Kholisoh dan Agung, (2011) yang menyatakan bahwa pengumuman dividen tidak memunculkan abnormal return yang signifikan sehingga disimpulkan pengumuman dividen turun atau dividen naik tidak berpengaruh terhadap aktivitas perdagangan di Bursa Efek Jakarta yang artinya investor menganggap pengumuman dividen bukan merupakan informasi yang cukup penting yang bisa mempengaruhi harga saham.

Di dunia pasar modal kita mengenal istilah Efisiensi Pasar Hipotesis sehubungan dengan pasar modal yaitu keadaan dimana harga sekuritas mencerminkan semua informasi yang relevan. Semakin cepat informasi direspon oleh pasar maka keadaan pasar semakin efisien. Salah satu informasi yang bisa digunakan untuk menguji efisiensi pasar adalah kebijakan dividen yang dapat dianalisis dengan melihat abnormal return yang terjadi disekitaran tanggal pengumuman dividen. Abnormal return adalah kelebihan dari return sesungguhnya terjadi terhadap return normal yang bisa jadi bernilai positif atau negatif. Kebijakan dividen bisa jadi merupakan informasi yang sangat penting bagi para investor karena mempengaruhi kesempatan investasi perusahaan, harga saham, struktur finansial, arus pendanaan dan posisi likuiditas yang bisa memunculkan reaksi pada pasar. dalam penenelitian ini pengujian data dilakukan di Bursa Efek Indonesia pada emiten yang termasuk kedalam Indeks LQ45 yaitu indeks yang terdiri dari 45 perusahaan yang paling aktif di perdagangkan di Bursa Efek Indonesia (BEI) dengan periode pengamatan tahun 2016 - 2018.

\section{KAJIAN LITERATUR}

\section{Dividen}

Menurut Hanafi (2014) dividen adalah keuntungan yang didapatkan investor disamping capital gain dari perdagangan saham. Ada dua jenis dividen yaitu dividen kas dan dividen nonkas. Dividen kas berupa pembayaran dividen secara tunai kepada para pemegang saham berdasarkan jumlah dividen yang sudah ditentukan pada Rapat Umum Pemegang Saham yang sudah dilakukan sebelumya yaitu sebelum pengumuman keputusan pembagian dividen. Dividen nonkas dapat berupa Stock dividen atau dividen berupa saham dan Stock Splits atau pemecahan saham.

\section{Dividend Irelevance Theory}

Dividen tidak memiliki pengaruh bagi nilai sebuah perusahaan berdasarkan penelitian Mondigliani dan Miller (1961) yang dikenal dengan istilah Dividen Irelevance Theory. Teori ini menganggap nilai suatu perusahaan ditentukan oleh jumlah laba bersih sebelum pajak dan kelas risiko perusahaan. Nilai perusahaan tidak dapat ditentukan berdasarkan persentase laba yang dibagikan kepada para investor dalam bentuk dividen. Nilai perusahaan hanya dipengaruhi oleh bagaimana cara perusahaan mengelola aset dan mengelola risiko.

\section{Dividend Relevance Theory}

Dividend Relevance Theory atau relevan dividen yang dikemukanan M. Gorden, John Linter, James Walter and Richardson menyatakan bahwa pengumuman dividen memiliki pengaruh terhadap nilai perusahaan dan harga saham perusahaan sehingga perusahaan yang membagikan dividen memberikan informasi positif bagi investor dan menunjukan kinerja perusahaan yang baik. Hal ini didukung dengan banyaknya penelitian yang mendukung teori ini salah satunya yaitu Farrukh et al. (2017) yang menyatakan ada pengaruh pengumuman dividen terhadap harga saham dan performa perusahaan juga pada penelitian Masum (2014) yang menyatakan bahwa kebijakan dividen secara signifikan memiliki pengaruh positif terhadap harga saham. Dividend Relevance Theory juga didukung teori lainnya seperti teori signal yang menyatakan bahwa harga saham akan naik jika dividen yang dibagikan naik dan harga saham juga akan turun jika dividen yang dibagikan turun. 
Sehubungan dividen naik ataupun dividen turun ada beberapa pendapat dan teori yang jua mendukung bahwa dividen memiliki pengaruh pada harga saham.

\section{Prosedur Pembagian Dividen}

Menurut Kholisoh dan Agung (2011) Pembagian dividen adalah suatu peristiwa yang dinantikan oleh para pemegang saham. Pembagian dividen oleh perusahaan dapat dilakukan secara kuartalan maupun tahunan, tergantung dari kebijaksanaan yang ditetapkan oleh masing-masing perusahaan. Adapun prosedur pembagian dividen menurut Hanafi (2014) adalah :

1. Tanggal Pengumuman adalah tanggal ketika dewan direksi perusahaan mengumumkan rencana pembagian dividen. Dewan direksi melakukan rapat, kemudian memutuskan untuk membayarkan dividen dalam jumlah tertentu. Pada saat kebijakan pembagian dividen diumumkan, perusahaan mempunyai kewajiban (liabilities) untuk membayar dividen (menjadi utang dividen) bagi perusahaan.

2. Tanggal Ex-Dividen (Ex- Dividend Date) adalah tanggal ketika pembeli saham sebelum tanggal tersebut memiliki hak atas dividen. Jika investor membeli saham sesudah tanggal tersebut atau pada tanggal tersebut, ia tidak berhak memperoleh dividen. Pada saat tanggal pencatatan, semua pemegang saham yang berhak atas dividen akan dicatat. Tanggal Exdividen biasanya ditetapkan 3 hari sebelum tanggal pencatatan. Tanggal Ex-dividen ditetapkan untuk mengakomodasi perbedaan efisien pencatatan pemegang saham saham oleh broker-broker yang berbeda .

3. Dividen dibayarkan kepada pemegang saham pada tanggal pembayaran kepada semua pemegang saham yang sudah tercatat berhak atas Dividen.

Meskipun secara formal tanggal pencatatan adalah tanggal penting, tetapi secara ekonomis, tanggal Ex-dividen merupakan tanggal yang penting bagi pemegang saham secara ekonomis. Investor yang membeli sebelum tanggal Ex-dividen, berhak memperoleh dividen.

\section{Dampak Pembagian Dividen}

Menurut Kholisohdan Agung (2011) Pembagian dividen dapat dilakukan dengan cara kuartalan atau tahunan, tergantung kebijakan Rapat Umum Pemegang saham masing-masing perusahaan. Investor pada yang melakukan pembelian pada ex- dividend date secara tidak langsung akan memiliki pemikiran bahwa pembagian dividen bisa memberikan dampak pada harga saham. Pemikiran oleh investor ini disebabkan karena pemegang saham telah kehilangan hak atas return dari dividen yang menyebabkan harga saham akan turun dan melihat prospek kedepan perusahaan yang membagi dividen berdasarkan pada pemikiran Husnan, (2001) dalam Kholisoh dan Agung (2011), yang pertama yaitu pemegang saham yang memiliki keinginan mendapat keuntungan dari capital gain, memilih untuk tidak membeli saham tersebut atau saham ex- dividend date yang kemudian harga saham yang sudah melakukan pembagian dividen tersebut akan turun harganya sebanding dengan nilai dari return yang telah hilang.

Pemikiran yang kedua, pemegang saham berfikiran jika perusahaan mengeluarkan uang dalam jumlah tertentu untuk membayar dividen kepada para pemegang saham, maka dapat mempengaruhi aliran kas (cash flow) dan laba ditahan keuangan perusahaan yang nantinya akan mempengaruhi operasi perusahaan yaitu ketika seharusnya perusahaan memiliki dana tambahan dari laba ditahan untuk reinvestasi pada proyek baru. Apabila dana yang dikeluarkan oleh perusahaan bisa mengganggu jalannya operasi, secara tidak langsung bisa mengakibatkan perusahaan mengalami kesulitan keuangan yang akhirnya akan mempengaruhi kinerja perusahaan. Adanya dua pemikiran yang secara logika nantinya bisa mendorong harga saham atau nilai saham di pasar modal mengalami penurunan yang dalam hal ini artinya peristiwa pengumuman dividen memililiki dampak atau pengaruh untuk membangun asumsi investor terhadap suatu perusahaan dan juga berpengaruh pada harga saham suatu perusahaan. .

\section{Hipotesis Pasar Efisien}

Bentuk pasar yang efisien adalah keadaan dimana harga mencerminkan sepenuhnya informasi yang tersedia dan sebagai implikasinya harga akan bereaksi dengan cepat tanpa adanya bias terhadap informasi baru. Efisiensi pasar menggambarkan hubungan antara harga-harga saham suatu sekuritas dengan ketersediaan informasi. Konsep pasar yang efisien lebih menekankan pada aspek informasi yang artinya suatu pasar yang dikatakan efisien adalah pasar yang dimana harga sekuritas telah mencerminkan semua informasi yang tersedia. Berdasarkan tingkat efisiensinya, terdapat tiga bentuk efisiensi pasar menurut Anoraga dan Pakarti (2001:85) dalam Ady and Mulyaningtyas (2017), yaitu :

1. Pasar efisien bentuk lemah (weak form) Adalah keadaan pasar modal dimana semua informasi dari masa lalu (seperti harga dan volume perdagangan ) sudah tercermin pada harga saham saat ini. Oleh karena itu, informasi masalalu tersebut tidak bisa digunakan oleh investor untuk memprediksi perubahan harga dimasa yang akan datang karena sudah tercermin pada harga saham saat ini. Dalam 
pasar efisien bentuk lemah investor tidak akan bisa mendapatkan abnormal return dari informasi harga dari harga masa lalu.

2. Pasar efisien bentuk setengah kuat (semi strong) Pasar efisien dalam bentuk setengah kuat adalah keadann pasar dimana harga saham saat ini sudah mencerminkan semua informasi yang sudah dipublikasikan (seperti earning, deviden, pengumuman stock split, penerbitan saham baru dan kesulitan keuangan perusahaan) sampai kepada para investor. Tujuan menguji pasa modan setengah kuat adalah untuk meminimalkan kesalahfahaman informasi mengenai kondisi perusahaan dan dimaksudkan untuk menjelaskan dan menggambarkan keakuratan nilai dari suatu saham yang telah dikeluarkan oleh suatu emiten, sehingga semua informasi yang relevan dipublikasikan sudah mencerminkan harga saham saat ini. Dalam efisiensi pasar bentuk setengah kuat seorang investor tidak bisa mendapatkan abnormal return dalam jangka wakru tertentu jika hanya berdasarkan informasi yang telah dipublikasikan.

3. Pasar efisien bentuk kuat (strong form) Pasar modal efisien dalam bentuk kuat adalah merupakan tingkat efisien pasar yang paling tinggi. Istilah pasar efisien bentuk kuat bisa menjelaskan bahwa semua informasi dicerminkan dalam harga saham baik informasi terpublikasi maupun informasi yang tidak terpublikasi (private information), sehingga dalam pasar modal efisien bentuk kuat tidak ada seorang pun investor yang bisa memperoleh abnormal return. Private Information adalah sebuah informasi yang hanya mungkin diketahui oleh orang dalam perusahaan dan bersifat sangat rahasia karena sebuah alasan strategi. Semakin tinggi tingkat efisiensi pada sebuah pasar modal maka semakin sulit bagi seorang investor untuk mendapatkan abnormal return dari pasar.

\section{Indeks LQ45}

Menurut Hartono (2016) Pasar modal Indonesia masih tergolong yang transaksinya dianggap tipis (thin market), karena sebagian sekuritas yang ada di pasar saham Indonesia sebagian besar tidak terlalu aktif diperdagangkan. IHSG dianggap kurang bagus sebagai indikator kegiatan pasar modal karena sebagian besar perusahaan yang ada di dalamnya tidak aktif diperdagangkan sehingga dapat mempengaruhi penghitungan hasil pergerakan IHSG. Tanggal 24 Februari 1997 diperkenalkan indeks alternatif yaitu Index LQ45 yang sekarang merupakan salah satu indeks dari 22 jenis indeks yang ada di Bursa Efek Indonesia (BEI). Indeks LQ45 dibentuk hanya dari 45 saham-saham yang paling aktif diperdagangkan. Syarat sebuah perusahaan masuk kedalam Indeks
LQ45 adalah liquiditas dan kapitalisasi pasar dengan kriteria sebagai berikut :

1. Selama 12 bulan terakhir memiliki rata-rata transaksi saham perusahaannya masuk dalam urutan 60 terbesar di pasar saham regular.

2. Nilai kapitalisasi pasarnya masuk dalam urutan 60 besar di pasar regular selama 12 bulan terakhir.

3. Minimal 3 bulan tercatat di Bursan Efek Indonesia (BEI)

Indeks LQ45 diperbaharui setiap 6 bulan sekali, yaitu pada bulan Februari dan Bulan Agustus. (Hartono,2016 : 156).

\section{Studi Peristiwa (Event Study)}

Menurut Hartono (2016 : 623) Studi peristiwa (Event Study) merupakan sebuah studi atau ilmu yang mempelajari reaksi pasar terhadap sebuah peristiwa (Event) yang dipublikasikan sebagai suatu pengumuman atau sebuah keputusan perusahaan. Event study bisa digunakan untuk mengetahui kandungan informasi dari suatu peristiwa dan dapat juga digunakan untuk mengetahui tingkat efisiensi pasar bentuk setengah kuat. Reaksi pasar ditunjukan dengan adanya perubahan dari harga sekuritas bersangkutan. Abnormal return dapat dijadikan alat ukur untuk menguji reaksi pasar saham. Jika dilakukan uji abnormal return, maka suatu pengumuman yang memiliki kandungan informasi akan memberikan abnormal return pada harga saham. Sebaliknya jika pengumuman yang diuji tidak memiliki kandungan informasi tidak akan ada abnormal return pada harga saham.

\section{Abnormal return (Return Tak Normal)}

Menurut Hartono (2016 : 647) abnormal return ( return tak normal) adalah kelebihan dari return yang sesungguhnya terhadap return normal. return normal merupakan return ekspektasi (return yang diharapkan investor). Abnormal return dapat diperoleh dengan menghitung selisih antara return sesungguhnya dengan return ekspektasi. Return realisasi atau return sesungguhnya adalah return yang terjadi pada suatu waktu yang merupakan selisih harga sekarang terhadap harga saham sebelumnya atau dapat dihitung dengan rumus $\left(\mathrm{P}_{\mathrm{i}, \mathrm{t}}\right.$ $\left.-\mathrm{P}_{\mathrm{i}, \mathrm{t}-1}\right) / \mathrm{P}_{\mathrm{i}, \mathrm{t}-1}$. Sedangkan return ekspektasi dapat di diestimasi dengan beberapa model yaitu meanadjusted model, market model, market-adjusted model dan capital asset pricing model (CAPM).

\section{Capital Asset Pricing Model (CAPM)}

Berdasarkan Hartono (2016 :555) yang menyatakan bahwa penghitungan return merupakan kemampuan yang harus dimiliki seorang investor untuk mengetahui seberapa besar keuntungan yang biasa ia dapatkan jika membeli saham suatu perusahaan tertentu dan apakah sebanding dengan risiko yang dihadapi. Untuk mengestimasi return 
harapan suatu sekuritas digunakan sebuah model penghitungan yang disebut Capital Asset Pricing Model (CAPM) yaitu model yang dianggap cukup ideal untuk mengestimasi return yang diharapkan investor berdasarkan risiko yang dihadapi didukung oleh pengujian yang dilakukan Rosyidah (2018) yang menyatakan bahwa Capital Asset Pricing Model (CAMP) lebih akurat dibandingkan Arbitrage Pricing Theory untuk memprediksi return saham. Terdapat model lain yang dapat digunakan dalam mengestimasi return harapan yaitu mean-adjusted model yang menganggap return harapan bernilai konstan dan sama dengan rata return realisasi sehingga dianggap kurang karena tidak memperhatikan risiko sistematis seperti pada CAPM. Model lain yaitu marketadjusted model yang menganggap return sekutitas adalah return indeks pasar sehingga dianggap tidak lebih baik dari CAPM karena tidak memperhitungkan risiko sistematis.

Bentuk standar dari model CAPM untuk pertama kali dikembangkan secara terpisah oleh Sharpe (1964), Lintner (1965) dan Mossin (1969) oleh karena itu model ini sering disebut CAPM model Sharpe-Lintner-Mossin ( Hartono 2016) Formula yang digunakan dalam mengestimasi return harapan dengan model ini adalah :

$$
\mathrm{E}\left(\mathrm{R}_{\mathrm{i}}\right)=\mathrm{R}_{\mathrm{BR}}+\beta_{\mathrm{i}}\left[\mathrm{E}\left(\mathrm{R}_{\mathrm{M})}-\mathrm{R}_{\mathrm{BR}}\right]\right.
$$

Dimana : $\mathrm{E}\left(\mathrm{R}_{\mathrm{i}}\right)=$ tingkat return individu yang diharapkan( ekspek return)

$\mathrm{E}\left(\mathrm{R}_{\mathrm{M})}=\right.$ return indeks pasar pada periode pengamatan

$\mathrm{R}_{\mathrm{BR}} \quad=$ tingkat bunga bebas risiko

$\beta_{\mathrm{i}} \quad=$ Tingkat risiko sistematis

Formula CAPM ditemukan istilah beta atau tingkat risiko sistematis yang dalam hal ini menurut Hartono (2016: 443) merupakan suatu pengukuran volatilitas return suatu sekuritas atau return portofolio terhadap return pasar. Beta merupakan salah satu bagian yang menjadi kelebihan model CAPM karena model ini memperhitungkan risiko sistematis pasar yang tentunya mempengaruhi ekspek return suatu sekuritas. Disisi lain CAPM tetap memiliki kekurangan yaitu model ini sebenarnya belum bisa menggambarkan variasi return dan risiko secara tepat karena model ini mengasumsikan kondisi pasar yang seimbang dan efisien.

\section{METODE PENELITIAN}

Penelitian ini dilaksanakan di PT. Triboga Jaya (RM. Sunda Rasa) Kota Sukabumi. Menggunakan pendekatan manajemen pemasaran, yang Penelitian ini merupakan penelitian Event Study yang menurut Hartono (2016) merupakan
Study yang mempelajari reaksi pasar terhadap suatu peristiwa (event) yang informasinya dipublikasikan sebagai suatu pengumuman, sehingga Event Study dapat digunakan untuk melihat reaksi pasar modal melalui pergerakan harga saham terhadap suatu peristiwa tertentu. Unit analisis dalam penelitian ini berupa data harga saham harian (historical price) yang diperoleh dari berbagai sumber seperti Bursa Efek Indonesia (BEI), situs internet dan sumbersumber lain yang sesuai dengan tujuan penelitian.Populasi dalam penelitian ini adalah 45 perusahaan yang terdaftar di Bursa Efek Indonesia (BEI) yang termasuk kedalam Index LQ45 dan sampel dari penelitian ini adalah 27 perusahan didalam Index LQ45 yang melakukan pembagian dividen periode tahun 2016-2018. Teknik pengumpulan data dalam penelitian ini adalah pengambilan sampel secara non probabilitas berupa purposive sampling atau pengambilan sampel bertujuan dengan maksud agar data-data yang dikumpulkan sesuai dengan tujuan penelitian dan mengurangi bias. Penelitian ini melakukan analisi data dengan uji beda terhadap rata-rata abnormal return sebelum dan sesudah peristiwa yang bertujuan untuk melihat apakah ada perbedaan abnormal return saham sebelum dan sesudah tanggal Ex-dividend date.

\section{HASIL PENELITIAN DAN PEMBAHASAN}

Hasil Pengujian hipotesis untuk membuktikan hipotesis yang dibuat sebelumnya yaitu untuk membuktikan apakah ada perbedaan abnormal return sebelum dan sesudah Ex-dividend date pada saat pengumuman dividen naik dan dividen turun. Hasil pengujian hipotesis adalah sebagai berikut :

\section{Pengujian Hipotesis pada Pengumuman Dividen Turun}

Sebelum melakukan uji beda terlebih dahulu dilakukan uji normalitas data menggunakan SPSS.22 dan diperoleh hasil sebagai berikut :

$$
\text { Tabel }
$$

Hasil Uji Normalitas Data Pada Pengumuman Dividen Turun

\begin{tabular}{ccc}
\hline Pengujian & $\begin{array}{c}\text { Taraf } \\
\text { Signifikansi } \\
\text { Uji Beda }\end{array}$ & $\begin{array}{c}\text { Signifikansi } \\
\text { Hasil Uji } \\
\text { Beda }\end{array}$ \\
\hline $\begin{array}{c}\text { Normalitas Data } \\
\text { (sebelum) }\end{array}$ & 0,05 & 0,153 \\
\hline $\begin{array}{c}\text { Normalitas Data } \\
\text { (sesudah) }\end{array}$ & 0,05 & 0,997 \\
\hline
\end{tabular}

Berdasarkan tabel 5.3 uji normalitas diatas diperoleh nilai signifikansi sebesar 0,153 dan 0,997 yang artinya lebih besar dari 0,05 $(>0,05)$ maka dapat disimpulkan data penelitian berdistribusi 
normal. Selanjutnya dapat dilanjutkan uji paired sample t-test dengan menggunakan SPSS.22 dan hasil yang diperoleh adalah :

\section{Tabel}

Hasl Uji Beda Pada Dividen Turun

\begin{tabular}{ccc}
\hline Pengujian & $\begin{array}{c}\text { Taraf } \\
\text { Signifikansi } \\
\text { Uji }\end{array}$ & $\begin{array}{c}\text { Signifikansi } \\
\text { Hasil Uji }\end{array}$ \\
\hline $\begin{array}{c}\text { Paired sample } \\
\text { test }\end{array}$ & 0,05 & 0,486 \\
\hline
\end{tabular}

Berdasarkan tabel 5.4 di atas diperoleh hasil bahwa nilai signifikansi sebesar 0,486 yang artinya lebih besar dari taraf signifikansi $0,05(>0,05)$ yang dapat di simpulkah bawa $\mathrm{H}_{0}$ diterima yang artinya tidak ada perbedaan abnormal return saham sebelum dan sesudah Ex-dividend date pada pengumuman dividen turun.

\section{Pengujian Hipotesis pada Pengumuman Dividen Naik}

Sebelum melakukan uji beda terlebih dahulu dilakukan uji normalitas data menggunakan SPSS.22 dan diperoleh hasil sebagai berikut :

Tabel

Hasil Uji Normalitas Data Pada Pengumuman Dividen Naik

\begin{tabular}{ccc}
\hline Pengujian & $\begin{array}{c}\text { Taraf } \\
\text { Signifikansi } \\
\text { Uji Beda }\end{array}$ & $\begin{array}{c}\text { Signifikansi } \\
\text { Hasil Uji } \\
\text { Beda }\end{array}$ \\
\hline $\begin{array}{c}\text { Normalitas Data } \\
\text { (sebelum) }\end{array}$ & 0,05 & 0,003 \\
\hline $\begin{array}{c}\text { Normalitas Data } \\
\text { (sesudah) }\end{array}$ & 0,05 & 0,005 \\
\hline
\end{tabular}

Berdasarkan tabel 5.5 uji normalitas diatas diperoleh nilai signifikansi sebesar 0,017 dan 0,002 yang artinya kurang dari dari $0,05(<0,05)$ maka dapat disimpulkan data penelitian tidak berdistribusi normal. Mendapati data yang tidak berdistribusi normal maka pengujian selanjutnya harus dilakukan dengan uji statistik nonparametrik yang fungsinya sama menguji beda dua rata-rata yaitu uji peringkat bertanda Wilcoxon yang dapat dilakukan dengan SPSS.22. Hasil pengujiannya sebagai berikut:

\section{Tabel}

\section{Hasil Uji Wilxocon related sample test}

\begin{tabular}{ccc}
\hline Pengujian & $\begin{array}{c}\text { Statistik } \\
\text { Hitung }\end{array}$ & $\begin{array}{c}\text { Statistik } \\
\text { tabel }\end{array}$ \\
\hline $\begin{array}{c}\text { Wilxocon } \\
\text { related sample } \\
\text { test }\end{array}$ & 1,376 & 1,645 \\
\hline
\end{tabular}

Berdasarkan tabel 5.6 di atas, hasil uji wilxocon menunjukan Statistik hitung (z hitungn) adalah 1,376. Sedangkat statistik tabel ( $\mathrm{z}$ tabel) bisa dihitung dengan $\alpha=5 \%$, maka luas kurva normal adalah $50 \%-5 \%=45 \%$ atau 0,045 pada tabel $\mathrm{z}$ maka diperoleh niai t-tabelnya adalah 1,645. Karena nilai $\mathrm{z}$ hitung lebih kecil daripada $\mathrm{z}$ tabel maka $\mathrm{H}_{0}$ diterima yang artinya tidak ada perbedaan abnormal return saham sebelum dan sesudah $E x$ dividend date pada pengumuman dividen naik.

\section{Dividen Naik}

Berdasarkan teori signal saat dilakukan pengumuman dividen naik akan membuat harga saham naik yang artinya investor akan bereaksi positif pada saat dividen naik dan bisa terjadi abnormal return positif bagi investor. Investor yang percaya pada Bird in the hand Theory adalah investor yang lebih menyukai dividen naik atau dividen yang tinggi karena mereka mengatakan dividen lebih pasti dari pada capital gain. Dividen yang tinggi dianggap akan mengurangi ketidak pastian daripada capital gain yang tidak pasti dimasa mendatang. Investor yang mempercayai teori agensi juga mendukung pembayarn dividen tinggi atau dividen naik karena akan mengurangi potensi konflik antar manager dengan pemegang saham yang artinya investor yang mempercayai teori- teori di atas akan berekasi pada pengumuman dividen naik.

Berdasarkan hasil analisis data dan uji hipotesis tidak terdapat perbedaan abnormal return saham sebelum dan sesudah tanggal ex-dividend date pada pengumuman dividen naik. Hasil dari penelitian ini memberikan informasi bahwa ada dukungan teoritis terhadap dividend irelevance theory yang dikemukakan Mondigliani dan Miller (1961) yang menyatakan bahwa kebijakan dividen tidak memiliki pengaruh tehadap nilai perusahaan. Hasil penelitian lain juga sependapat dengan MM, Kayana, Tommy and Maramis (2018) yang dengan hasil penelitiannya menyatakan tidak ada perbedaan abnormal return saham sebelum dan sesudah pengumuman dividen tahun 2016-2017. Omodero dan Amah (2017) juga menemuka bahwa pembagian dividen tidak mempengaruhi harga saham karena investor tidak befokus pada dividen tetapi lebih percaya pada kemampuan manajemen dalam mengelola keuangan perusahaan. Penelitian lain juga mendukung bahwa pengumuman dividen tidak berpengaruh pada harga saham oleh Kholisoh dan Agung (2011) yang menyatakan bahwa pengumuman dividen tidak berpengaruh terhadap aktivitas perdagangan di Bursa Efek Jakarta yang artinya investor menganggap pengumuman dividen bukan merupakan informasi yang cukup penting yang bisa mempengaruhi harga saham sehingga tidak terlihat reaksi pasar yang bisa menimbulkan adanya perbedaan abnormal return sebelum dan sesudah ex-dividend date pada pegumuman dividen naik. Tidak ada abnormal return pada pengumuman dividen naik bisa menunjukan bahwa pasar modal di Indonesia terutama pada indeks LQ45 sudah efisien dalam bentuk setengah kuat 
karena tidak ada investor yang bisa mendapatkan abnormal return yang signifikan dari panguman dividen naik.

\section{Dividen Turun}

Pengumuman dividen turun akan membuat harga saham akan turun berdasarkan teori signal dan argumen lain yang menyatakan dividen turun atau dividen rendah lebih disukai beberapa investor karena pajak yang berbeda pada dividen dan capital gain. Dibeberapa negara pajak untuk dividen lebih besar daripada pajak untuk capital gain sehingga investor lebih menyukai dividen yang rendah atau dividen turun. Investor yang mempercayai teori di signal dan argumen tentang pajak akan bereaksi pada pengumuman dividen turun.

Berdasarkan hasil analisis data dan uji hipotesis tidak terdapat perbedaan abnormal return saham sebelum dan sesudah tanggal ex-dividend date pada pengumuman dividen turun. Hasil dari penelitian ini memberikan informasi bahwa ada dukungan teoritis terhadap dividend irelevance theory yang dikemukakan Mondigliani dan Miller (1961) yang menyatakan bahwa kebijakan dividen tidak memiliki pengaruh tehadap nilai perusahaan. Hasil penelitian lain juga sependapat dengan MM, Kayana, Tommy and Maramis (2018) yang dengan hasil penelitiannya menyatakan tidak ada perbedaan abnormal return saham sebelum dan sesudah pengumuman dividen tahun 2016-2017. Omodero dan Amah (2017) juga menemuka bahwa pembagian dividen tidak mempengaruhi harga saham karena investor tidak befokus pada dividen tetapi lebih percaya pada kemampuan manajemen dalam mengelola keuangan perusahaan. Penelitian lain juga mendukung bahwa pengumuman dividen tidak berpengaruh pada harga saham oleh Kholisoh dan Agung (2011) yang menyatakan bahwa pengumuman dividen tidak berpengaruh terhadap aktivitas perdagangan di Bursa Efek Jakarta yang artinya investor menganggap pengumuman dividen bukan merupakan informasi yang cukup penting yang bisa mempengaruhi harga saham sehingga tidak terlihat reaksi pasar yang bisa menimbulkan adanya perbedaan abnormal return sebelum dan sesudah ex-dividend date pada pegumuman dividen turun. Tidak ada abnormal return pada pengumuman dividen turun bisa menunjukan bahwa pasar modal di Indonesia terutama pada indeks LQ45 sudah efisien dalam bentuk setengah kuat karena tidak ada investor yang bisa mendapatkan abnormal return yang signifikan dari panguman dividen turun.

Pengumuman dividen dianggap penting bagi sebagian investor karena kebijakan dividen merupakan informasi yang mempengaruhi kesempatan investasi perusahaan, struktur finansial, arus pendanaan dan posisi likuiditas. Artinya, kebijakan dividen menyediakan informasi mengenai performa suatu perusahaan yang bisa jadi memunculkan reaksi positif bagi investor yang memandang posotif suatu pemgumuman dividen atau reaksi negatif bagi investor yang memandang negatif suatu pengumuman dividen. Persepsi yang bisa memunculkan reaksi investor ternyata tidak terlihat pada hasil uji perbedaan abnormal return saham sebelum dan sesudah ex-dividend date terhadap pengumuman dividen naik atau dividen turun yang telah dilakukan pada Indeks LQ45 tahun 2016- 2018.

Bagi para investor dan manager keuangan hasil penelitian ini bisa dijadikan referensi dalam menanggapi pengumuman dividen yang terbagi atas dividen turun atau dividen naik. Investor dan manager keuangan tidak perlu takut ketika terjadi pengumuman dividen turun karena pada kenyataannya tidak akan memunculkan perbedaan pada abnormal return saham sebelum dan sesudah pengumuman dividen turun. Pengumuman dividen naik juga tidak bisa diartikan langsung sebagai informasi positif karena tidak ada perbedaan abnormal return saham sebelum dan sesudah exdividend date pada pengumuman dividen naik yang artinya investor dan manager keungan tetap harus melihat kinerja perusahaan melalui informasi selain pengumuman dividen.

\section{PENUTUP}

\section{Kesimpulan}

Setelah melakukan penelitian maka dapat ditarik dua kesimpulan berikut ini :

1. Tidak terdapat perbedaan pada abnormal return saham sebelum dan sesudah Exdividend date pada perusahaan yang melakukan pengumuman dividen naik di Bursa Efek Indonesia perioda tahun 20162018.

2. Tidak terdapat perbedaan pada abnormal return saham sebelum dan sesudah Exdividend date pada perusahaan yang melakukan pengumuman dividen turun di Bursa Efek Indonesia perioda tahun 20162018.

\section{Saran}

Terdapat keterbatasan dalam penelitian ini, sehingga peneliti selanjutnya disarankan untuk :

1. Melakukan pengujian pada event lain dengan petimbangan tidak ada event lainnya yang berdekatan dengan event tersebut sehingga tidak akan memunculkan bias karena dua event yang berdekatan.

2. Memperhatikan corporate action yang dilakukan perusahaan yang menjadi objek penelitian yang bisa menjadi confounding effect seperti stock split, right issue, marger, akuisisi dan pengumuman lain yang bisa jadi variabel lain yang merancukan hasil penelitian. 


\section{DAFTAR PUSTAKA}

Ady, S. U. and Mulyaningtyas, A. 2017, Eksplorasi Tingkat Efisiensi Pasar Modal Indonesia Studi Kasus Di Bursa Efek Indonesia, Jurnal Bisnis dan Manajemen, 1(2), pp. 103-123.

Chaabouni, I. 2017, Impact Of Dividend Announcement On Stock Return:A Study Of Listed Companies In Saudi Arabia Financial Markerts, Business and management, 9(1), pp. 1-13.

Farrukh, K. et al. 2017, Impact of dividend policy on shareholders wealth and firm performance in Pakistan, Cogent Business \& Management. Cogent, 4(1), pp. 1-11.

Hanafi, Mamduh M. 2014, Manajemen Keuangan. BPFI-YOGYAKARTA. Yogyakarta

Hartono, Jogiyanto 2016, Teori Portofolio dan Analisis Investasi. Edisi 10. BPFE. Yogyakarta.

http//:www.ksei.co.id/files/uploads/press_releases/p ress_file/id-id/135_berita_ pers_ksei_terus_upayakan_kemudahaan_pe mbukaan_rekening_investasi_20170816154 208.pdf (Diakses 2018)

Kayana, F. N., Tommy, P. and Maramis, J. B. 2018, Reaksi Investor Pasar Modal Indonesia Tehadap Pengumuman Dividen (Studi Kasus Pada Perusahaan Asuransi Yang Terdaftar Di Bursa Efek Indonesia Tahun 2016-2017), Jurnal EMBA: Jurnal Riset Ekonomi,

Manajemen, Bisnis dan Akuntansi, 6(3), pp. 1208-1217.

Kholisoh, L. and Agung, R. S. 2011, Pengaruh Pengumuman Dividen Terhadap Perubahan Harga Saham: Studi Di Bursa Efek Jakarta (BEJ), Universitas Gunadarma Jakarta, pp. 39-52.

Kusno, john iwan and Hartanto, F. T. 2017, Analysis of Dividend Policy and Its Impact on Shareholders Wealth Maximization in Nigerian Firms (A Study of Brewery Industry), Economics and Finance, 4(5), pp. 441-452.

Luhur, S. 2010, Reaksi Pasar Modal Indonesia Seputar Pemilihan Umum 8 Juli 2009 pada Saham LQ-45, Jurnal Keuangan dan Perbankan, 14(2), pp. 249-262.

Masum, A. Al 2014, Dividend Policy and Its Impact on Stock Price - A Study on Commercial Banks Listed in Dhaka Stock Exchange, Global Disclosure og Economic and Business, 3(1), pp. 9-20.

Mondigliani, F. and Miller, M. H. 1961, Dividend policy, growth and the valuation of share, The journal of business, 34(4), pp. 441-433.

Omodero, C. O. and Amah, K. O. 2017, 'Analysis of Divided Policy and Its Impact on
Shareholders Wealth Maximization in Nigerian Firms (A Study of Brewery Industry)', Applied Economics and Finance, 4(5), p. 1

Oyinlola and Michael, O. 2014, The Impact Of Dividend Policy On Stock Prices Of Quoted Firms In Nigeria, International journal of economics,commerce and managemen. United Kingdom., II(9), pp. 1-17.

Pahlevi, M. R. 2008, Saham Perusahaan Sektor Keuangan Pada Saat Ex-Dividend Date Di Bursa Efek Indonesia ( BEJ ) Pada Tahun 2008', Jurnal Ekonomi dan akuntansi Universitas Gunadarma Jakarta.

Rosyidah, U. 2018, Analisis Keakuratan Capital Asset Pricing Model(Capm) Dan Arbritage Pricing Theory(Apt) Dalam Memprediksi Returnsaham Pada Perusahaan Yang Terdaftardalam Jakarta Islamic Index(JII) Periode Tahun 2015-2017, Fakultas Ekonomi dan Bisnis IslamInstitut Agama Islam Negeri SurakartaIslamInstitut Agama Islam Negeri Surakarta.

Simon-Oke, O. and Olugunwa, O. 2016, Evaluation Of The Effect Of Dividend Policy On The Performance Of Corporate Firm In Nigeria, FUTA Jurnal of management and technologi.

Sularso, A. R. 2003, Pengaruh Pengumuman Deviden Terhadap Perubahan Harga Saham Sebelum Dan Sesudah Ex-Dividend Date Di Bursa Efek Jakarta (BEJ), Jurnal akuntansi dan keungan, 5(1), pp. 1-17.

Sumani and Larasati, D. 2015, Analisis-Pengaruh Pengumuman Pembagian Dividen Terhadap Abnormal Return Pada Perusahaan Yang Terdapat Di Bursa Efek Indonesia Tahun 2013-2015, Jurnal akuntanis, 2, pp. 180190.

\section{Profil penulis}

Aulia Azizah, S.Pd, M.M , Mahasiswa Program Studi Magister Manajemen, Fakultas Ekonomi dan Bisnis,Universitas Lambung Mangkurat. Banjarmasin

Jl. Brigjen H. Hasan Basri, Pangeran, Kec. Banjarmasin Utara, Kota Banjarmasin, Kalimantan Selatan 70123, Indonesia

Email : aulia.azizah11@gmail.com 